\title{
The Palaeoecology of the Interglacial deposits at Histon Road, Cambridge
}

\author{
By B. W. Sparks and R. G. West, Cambridge
}

With 7 figures and 2 tables

\begin{abstract}
$\mathrm{Zus}$ ammenfassung. Von den interglazialen Schichten in Histon Road, Cambridge, ist ein 8-m-Kern gewonnen worden. Er gestattete eine genaue Untersuchung der Pflanzen- und der Land- und Süßwasser-Molluskenreste.

Die betreffenden Schichten gehören der Zone $g$ der letzten Interglazialzeit und der Zone $b-i$ an: letzteres Symbol soll andeuten, daß, obwohl die Kontinuität der Schichten nicht unterbrochen ist, die Picea-Zone, $b$, in diesem einzigen in Großbritannien bekannten Ausschnitt aus diesem Teil der letzten Interglazialzeit fehlt. Von Zone $f$ ist keine Spur gefunden worden.

$\mathrm{Um}$ ein Bild von der Paläoökologie zu bekommen, wurden die makroskopischen Pflanzenreste und Mollusken aus 41 Teilstücken inventarisiert, von denen jedes durchschnittlich $15 \mathrm{~cm}$ Länge hatte. Etwa 3000 Früchte und Samen und 16000 Mollusken wurden gefunden. Diese sind in ökologische und klimatische Verteilungsgruppen eingeteilt worden. Die Bedeutung der Variationen innerhalb dieser Gruppen wird behandelt. Die Pflanzenreste und Mollusken scheinen ein einheitliches Bild von einem Zustand zu bieten, der vom Sumpf bis zum fließenden Gewässer variiert, wie es von einem aufschüttend mäandrierenden Flusse zu erwarten ist.
\end{abstract}

R e s u mé. On a fait un sondage dans les sédiments marneux interglaciaires à Histon Road, Cambridge, pour faire une analyse corrélative des restes végétaux at des mollusques terrestres et fluviatiles. C'est le gisement le seul connu en Angleterre qui comprend les zones $g$ et $b-i$ de la dernière époque interglaciaire. On se sert du signe $b-i$, pour indiquer que la zone $h$, celle de Picea, manque, bien qu'il n'y ait aucune discontinuité visible dans les sédiments. On n'a pas trouvé la zone $f$, celle du Quercetum Mixtum.

Pour analyser en grand détail les changements du milieu physique, qui se produisaient pendant le depôt des marnes, on a tenu compte de 41 divisions dont chaque était d'une épaisseur moyenne de $15 \mathrm{~cm}$. Environ 3000 graines et fruits et 16000 mollusques, trouvés dans les marnes, ont été divisés en groupements climatiques et écologiques et on a discuté l'importance des changements de fréquence de ces groupements de graines et de moilusques. Tous les deux montrent qu'il y avait une variation du milieu physique de marais riverain jusqu'à pleine rivière tel qu'on attend d'une rivière alluvionnante qui serpente à travers sa propre plaine alluviale.

$\mathrm{S}$ u $\mathrm{m} \mathrm{m}$ a r y. The Last Interglacial deposits formerly exposed along Histon Road, Cambridge, have been cored and an attempt made to integrate the analyses of plants and mollusca. The beds cored are referred to zone $g$ of the Last Interglacial and to zone $h-i$, a symbol used to indicate that, although there appears to be no unconformity, the Picea zone $b$ is absent in this, the only known British section of this part of the Last Interglacial. No trace of zone $f$ was found.

In order to analyse the palaeoecology, the macroscopic plant remains and mollusca were recorded from 41 subdivisions, each representing on an average $15 \mathrm{~cm}$ of core. Some 3000 fruits and seeds and 16000 mollusca were recovered. These have been divided into environmental and climatic or distribution groups and the significance of variations of these groups discussed. The plant remains and the mollusca seem to present a consistent picture of conditions varying from riverside marsh to full stream conditions, such as might be expected from a shifting, aggrading river.

\section{Introduction}

It is obvious from earlier accounts (Hollingworth, Allison \& Godwin 1950, W ALKER 1953) that the Last Interglacial deposits underlying the Histon Road, Cambridge, are rich in both plants and mollusca. Unfortunately, the earlier of these accounts, although containing a detailed analysis of upwards of 5000 mollusca by KENNARD, does not contain a complete pollen diagram in the light of which the significance of the mollusca may be assessed, while the later paper, although recording in an almost complete pollen diagram the presence of Jessen \& Milthers' zones $g$ and $i$, listed only a few mollusca from two broad horizons. As the integration of frequency analyses of pollen, macroscopic plant 
remains and non-marine mollusca at Bobbitshole, Ipswich (WEST 1957, Sparks 1957) seemed capable of yielding an interesting reconstruction of natural conditions, it was decided to re-examine the Histon Road deposits in the same way. Because the beds are no longer exposed, this necessitated taking a $10 \mathrm{~cm}$ core through the deposits to a depth of 8 metres. For their assistance with the boring, we are greatly indebted to Dr. C. L. Forbes, Mr. C. W. Parkin, Mr. B. Seddon and Dr. D. Walker.

\section{Stratigraphy}

The following succession of deposits was exposed in the core:

$0-160 \mathrm{cms}$ Rusty yellow predominantly flint gravel, the uppermost $20 \mathrm{cms}$ being developed into the modern soil. This unpromising material was not sampled.

$160-230 \mathrm{cms}$ Predominantly grey silty marl with a streak of flint gravel at $170-180 \mathrm{cms}$.

$230-240 \mathrm{cms} \quad$ Grey-yellow flint gravel.

$240-300 \mathrm{cms}$ Brown silty marl containing towards the base more plant debris than in any other part of the core.

$300-340 \mathrm{cms}$ Grey silty marl.

$340-355 \mathrm{cms}$ Light rusty-brown silty sand.

$355-490 \mathrm{cms} \quad$ Grey silty marl becoming slightly brown near the base.

$490-510 \mathrm{cms}$ Grey sandy gravel, consisting predominantly of flints but with some erratic material, e.g. quartzite, fragments of Gryphaea and purple porphyrite.

$510-625 \mathrm{cms} \quad$ Brown silty marl.

$625-640 \mathrm{cms}$ Mottled brown grey silty marl.

$640-700 \mathrm{cms}$ Light grey silty marl.

$700-810 \mathrm{cms}$ Waterlogged grey flint gravel, probably resting on Gault Clay.

These divisions are shown by the side of the pollen diagrams on Figs. 1 and 2.

The general succession of (c) rusty gravel, (b) grey silty marl, (a) brown silty marl, agrees well with the lithological divisions of (c) sand and gravel, (b) grey mud, and (a) sepia mud of WALKER (1953), but the correlation with the section described earlier (Holingworth, Allison \& Godwin 1950) is less clear. Both of these earlier sections were within 100 metres of the present boring, which was taken in the south-west corner of the field between Arbury Rd. and Histon Rd. (very near the 43-foot spot height on Histon Rd. shown on the $1: 10,560$ map, Cambridgeshire XL S.W.).

\section{Pollen diagrams: zonation and comparisons}

The results of pollen analysis of the sediments are shown in Figs. 1 and 2, the first dealing with the pollen of trees and shrubs, and showing the relative proportions of various categories of pollen and spores, the second dealing with the herbaceous pollen and the spores.

Pollen was present in the silty marls in all the sequence except at the base, in cores 13 , 12 and the base of 11 , and at a few horizons in cores 1 and 2. Tree pollen frequency is shown in figure 1, expressed as the number of $2-\mathrm{cm}$ traverses required to count 100 tree pollen grains, an approximate and relative method of measurement.

The diagrams can be divided into two zones on the basis of the tree pollen: a lower zone with high values of Carpinus and Quercus pollen, and an upper zone where Carpinus and Quercus are replaced by Pinus and Betula. The boundary between the zones is taken at $500 \mathrm{cms}$. Although a stony layer separates the zones, it is believed that no great unconformity exists between them, because the vegetational trends, such as the increase of Betula and the decrease of Carpinus, are not greatly upset across the zone boundary. 


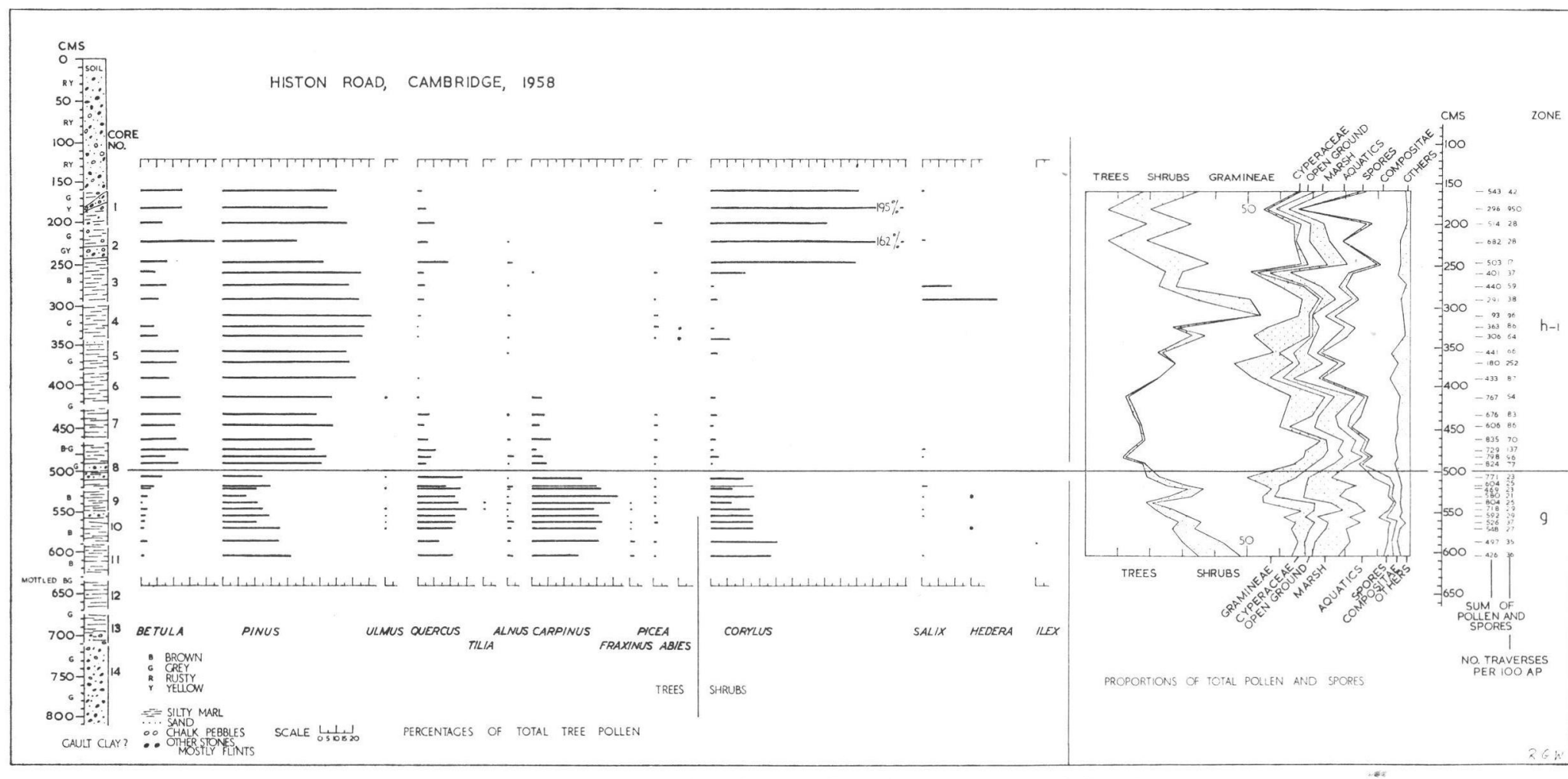

Figure 1. Tree and shrub pollen diagram through the Histon Road deposits. 


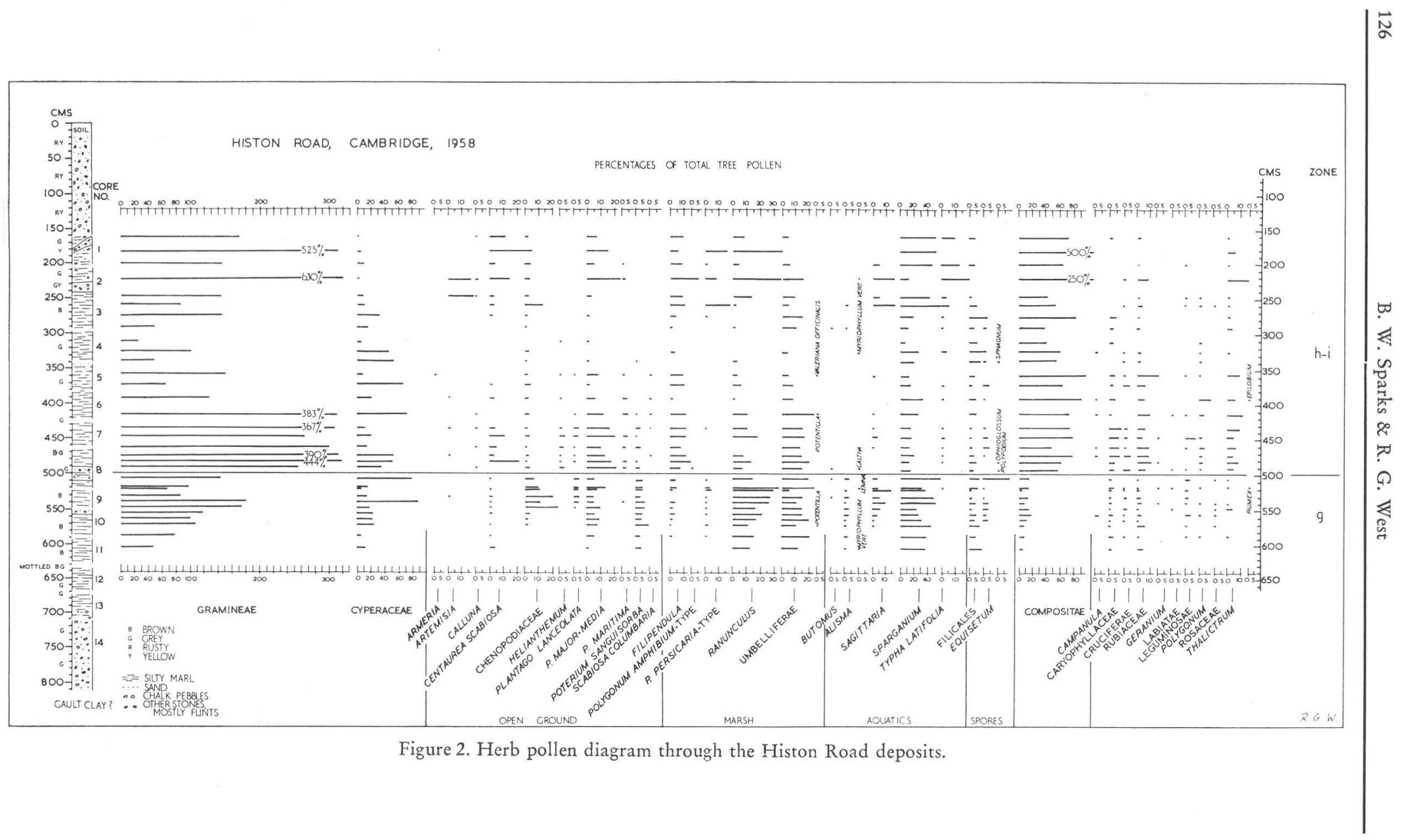


(A) Comparison with the previous pollen analyses from the $\mathrm{H}$ is ton Road.

WALKER's (1953) pollen diagram showed the zones, separated by a metre of unsampled deposit. These two zones are those identified in our pollen diagrams. The continuous sampling provided by our cores shows that only the transition between the zones is absent in WALKER's diagram. No trace was found in the recent boring of sediments from an older part of the Interglacial, although Hollingworth, Allison \& Godwin (1950) described such a sediment from the debris from a trench about 100 yards to the south.

(B) Comparison with the Interglacials of the north-west European mainland.

WaLKen suggested a correlation of the Histon Road deposits, on the basis of his pollen diagram, with zones $g$ and $i$ of the Eemian (Last) Interglacial. A sequence of pollen zones, $a$ to $n$, was described by Jessen \& Milthers (1928) on the basis of the pollen analysis of large numbers of Eemian Interglacial deposits in Jutland and northwest Germany. Zone $g$, the zone following the mixed oak forest zone $f$, is characterised by high values of Carpinus pollen, and zone $i$ by a predominance of Pinus pollen and impoverishment of the forest growth. On the continent these two zones are separated by zone $h$, a zone with high values of Picea pollen. The combination of a Carpinus zone, followed by a Picea, then a Pinus zone is at present unknown in the earlier interglacial periods of north-west Europe, and it seems satisfactory to conclude that the Histon Road zones are to be correlated with zones $g$ and $i$ of the Eemian Interglacial, even though zone $h$, the Picea zone, is absent.

(C) The absence of the Picea zone $b$.

Picea is a relatively low pollen producer compared with Betula and Pinus (FAEGRI \& Iversen 1950). The apparent absence of the Picea zone in the Histon Road diagram, though very low percentages of Picea pollen are recorded, may indicate either that the tree was absent from the region, the pollen arriving by long-distance transport, or that it was present only in small quantities. Edaphic or climatic factors may have prevented Picea from preading to the degree indicated by the high pollen percentages seen in the continental pollen diagrams. Thus the Pinus zone of the Histon Road deposits would appear to be contemporary with the Picea and Pinus zones of the continent, and therefore the Pinus zone is here labelled $b-i$.

\section{Secondary deposition of plant remains}

Certain changes which occur in the pollen analyses of the upper cores of zone $b-i$ have not yet been considered. The increases in the pollen percentages of Quercus and Corylus are the most noticeable. The percentages of the latter are much higher than in the lower samples, reaching $195 \%$ of the total tree pollen. But other features are not consistent with vegetational changes which might have resulted from an amelioration of the climate. Although Quercus and Corylus pollen percentages increase, the proportion of tree to non-tree pollen falls, and Betula and Pinus remain the dominant trees. The upper analyses also differ from the lower in the more abrupt changes in the tree pollen frequency and in the absence of pollen at various horizons in cores 1 and 2 .

In JESSEN \& MrLthers' (1928) scheme of the climatic development of the Eemian Interglacial, a middle bed with a sub-arctic flora (zone $k$ ) separated a lower temperate phase (zones $c$ to $i$ ) from an upper temperate phase (zones $l$ and $m$ ). But for the reasons given above, such climatic changes might be thought to account for the fluctuations in the frequencies of Quercus and Corylus pollen. However, ANDERSEN (1957) has recently shown that the upper temperate phase is not to be regarded as a part of the interglacial, the interglacial plant remains having been derived by reworking of the sediments formed 
during the lower temperate phase. As ANDERSEN points out, such reworking has been found in the upper layers of a number of interglacial deposits, e.g. at Hoxne (WEST 1956) and Wallensen im Hils (Thомson 1951), and it is presumably caused by changes in water level, probably aided by a cold climate with solifluxion.

Likewise, it is probable that the anomalous changes described above can be ascribed to the reworking of older sediments of the same interglacial and the consequent redeposition of pollen. In particular the values of Corylus and Quercus are thought to be caused by the reworking of zone $f$ deposits, which at other sites contain high values of Corylus and Quercus pollen. A similar effect was found in the Brørup Hotel Bog described by JESSEN \& Milthens (1928), where $133 \%$ Corylus was found in the so-called upper temperate phase, though only a maximum of $64 \%$ was recorded in the zone $f$ deposits of the lower temperate phase. In this instance also the Corylus rise was accompanied by a Quercus rise.

Thus there is no evidence that the upper fluctuations were accompanied by any climatic change. Moreover, it is impossible to say what is derived and what is not derived in the upper part of zone $b-i$. The difficulties which this imposes on the interpretation of the upper part of the pollen diagrams will be apparent in the later descriptions of the fauna, flora and climate.

\section{Regional vegetation history}

(A) Z o n e $g$.

During zone $g$ the temperate deciduons trees Quercus and Carpinus were widespread. The nut of Carpinus betulus found in the zone $g$ deposits suggests that this was the species concerned. Pinus and Corylus were also well-represented. Betula became more frequent towards the end of the zone. Low values of the pollen of Ulmus, Tilia, Alnus, Fraxinus and Picea indicate that these played no great part in the local vegetation though they may have been more abundant distantly.

The diversity of the neighbouring edaphic conditions, presuming as great a variety then as now, including soils formed from alluvium, gravels, chalky boulder clays of varying heaviness, Jurassic and Cretaceous clays, Lower Greensand and Chalk, means that the pollen must have been derived from many different plant communities, and this makes difficult a detailed interpretation of the pollen diagrams. It is probable that Carpinus betulus grew on the less heavy chalky boulder clay soils in the region, as well as on light, well-drained soils associated with Chalk thinly veiled by drift. At the present day, Quercus-Carpinus woods are commonly found on such soils in south-east England (M. Christy 1924).

The amount of tree pollen, however, is low compared with total of non-tree pollen, as seen in Fig. 1, and it appears that forest was by no means dominant. The frequencies of such plants as Centaurea scabiosa, Chenopodiaceae, Plantago lanceolata, P. major and/or media, Poterium sanguisorba and Gramineae mean much open ground. Certain of these species, such as Centaurea scabiosa, Plantago lanceolata, P. major and/or media and Poterium sanguisorba are characteristic of chalk grassland, such as is found a few miles to the south-east at the present day. The frequency and variety of the open ground plants suggest that the forest was patchy both nearby and on the Chalk to the south-east. (B) Z o n e $b$-i.

In spite of the probable presence of secondarily deposited pollen in the upper part of this zone, the main characteristics of the vegetation are clear. In zone $b-i$ Betula and Pinus have replaced the temperate trees of zone $g$ and, apart from a section in the middle of the zone, the low ratio of tree to non-tree pollen indicates that the forest was sparse. The pollen of Gramineae rises to large frequencies at the beginning of the zone; Compositae percentages show a similar trend, and so do the chalk grassland plants Centaurea scabiosa, Helianthemum and Plantago major and/or media. Other plants indicative of the presence 
of open ground in this zone are Armeria, Artemisia, Plantago maritima, Scabiosa columbaria and perhaps also Caryophyllaceae, Rubiaceae and Thalictrum. In cores 4, 5 and 6 the ratio of tree to non-tree pollen increases to $50 \%$, corresponding to a decrease of the frequencies of Gramineae pollen and other herbaceous types at these levels. It is difficult to determine whether this is of local or regional significance. Certainly above this phase the ratio of tree to non-tree pollen returns to very low values. A fuller interpretation of the upper part of the zone is prevented by the probable presence of derived pollen.

\section{Analysis of the macroscopic remains}

To ensure that the macroscopic plant remains and the mollusca came from exactly the same horizons, they were both washed out from the same sections of the cores. The usual procedure was to analyse each $40 \mathrm{~cm}$ core in three divisions, the bottom half complete and the upper half in two $10 \mathrm{~cm}$ sections giving the standard divisions, B, TB and TT (Table II). If contamination occurs it will affect the top of the core in the TT division. Where lithological variation is considerable the cores were more finely divided, e. g. core 8 , as they also were near the top of the section where the grey silty marl seemed to be involved by frost-heaving with the overlying gravel. Cores 14 and 13 were undivided because of the low frequency of mollusca therein.

The washing down and sorting were performed in the same way as with the Bobbitshole material (SPARKs 1957) and the same precautions taken in counting the mollusca.

\section{The general nature of the molluscan fauna}

Although there are at least 34 land species, compared with 33 freshwater species, freshwater mollusca are far more abundant than land mollusca, as may be seen by comparing figures 3 and 4 . But there are such considerable variations through the deposit, which will be discussed below, that any general characterisation of the bulk fauna from all horizons is of little use.

Curiously, only two species, now extinct in Britain, were found in the core: Bithynia leachi var. inflata, which had not been recorded before, and Clausilia pumila, recorded in both the previous accounts. Helicella crayfordensis (=Candidula radigueli BourguIGNAT) was also recorded from both earlier investigations, but no trace of it was found in the core. The same is true of two other extinct species recorded earlier, namely Corbicula fluminalis (Hollingworth, Allison \& Godwin 1950) and Vallonia pulchella var. enniensis (SPARKs 1953). Segmentina micromphala, recorded in 1950, may indicate a sixth extinct species, but it is probably best regarded as a variety of Segmentina nitida. Marstoniopsis steinii, recorded by KENNARD in the 1950 list as new to the British Pleistocene, has been recorded from the Cromer Forest Bed as Bythinella steinii, living as Amnicola taylori, and is now listed as Bytbinella scholtzi (ELLIS 1951). The extinct species are mainly south and south-east European forms, while C. fuminalis now lives in sub-tropical Africa and western Asia. Although cores are ideal for analysing plants and mollusca horizon by horizon, they may well not include rare extinct species, which can more readily be picked out in open sections.

\section{Variations in the local environment}

In order to assess variations in local conditions, several broad groupings of species were made and the percentage frequencies of these groups at different levels plotted in graphical form (Figs. 3, 4 and 5).

(A) Variations indicated by the mollusca.

The primary division is into land and freshwater species, each expressed as a percentage of the total mollusca and plotted on the left hand sides of Figs. 3 and 4. 


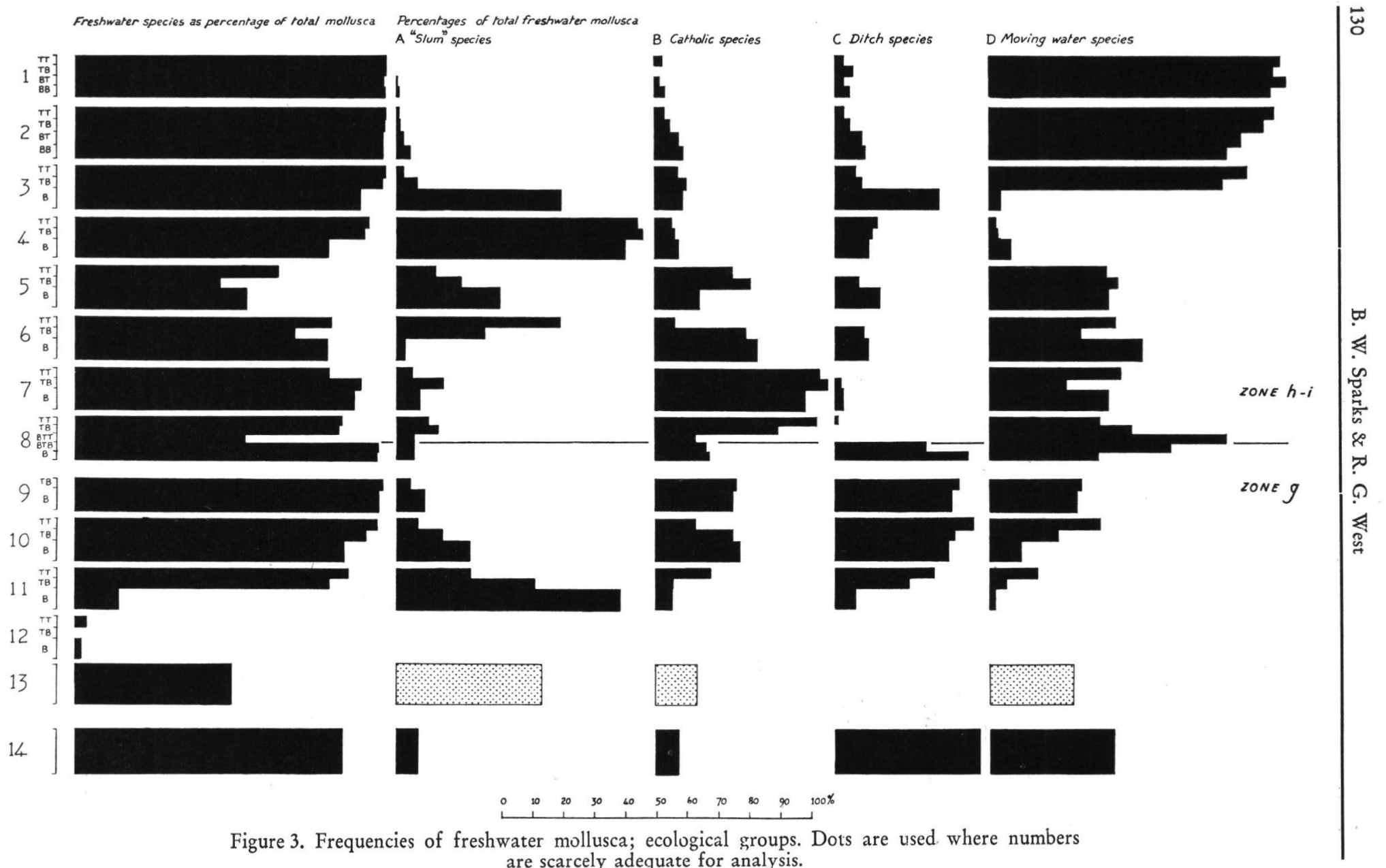


The freshwater mollusca were subdivided into four habitat groups, mainly on the basis of Boycotr's work (1936). These groups are somewhat arbitrary, as many mollusca are found in a wide range of habitats, but the relative abundance of the different groups should give a reasonable indication of local conditions.

The first group, A, the slum species as they were graphically described by Boycort, includes seven species, Lymnaed truncatula, Aplexa bypnorum, Planorbis leucostoma, Sphaerium lacustre, Pisidium casertanum, $P$. personatum, and $P$. obtusale. Of these, Planorbis leucostoma and Pisidium obtusale are the two which most affect the percentage frequency of the group and they are both characteristic of small closed water bodies subject to periods of drought. Some of the other species in this group will tolerate such conditions though they do not necessarily prefer them. Lymnaea truncatula may spend as much time on mud at the edge of the water as in the water and is regarded by Boycotr as not really a freshwater species.

The second group, B, the catholic species, has a wide tolerance of habitats and includes ten species, Lymnaea palustris, L. peregra, Planorbis albus, P. crista, P. contortus, Segmentina complanata, Sphaerium corneum, Pisidium milium, $P$. subtruncatum and $P$. nitidum. Most of the species may inhabit small bodies of water such as cattle ponds and also good localities in streams, though they are not usually found in the environments tolerated by the slum species of group A. It is significant that they are found in smaller numbers and more evenly distributed through the various horizons than most of the species included in the other groups. Planorbis crista seems to show greater fluctuations of frequency than the others.

The third group, C, the ditch species, prefer quietly moving water and a rich growth of water plants. Seven species are included, Valvata cristata, Planorbis planorbis, $P$. vorticulus, $P$. vortex, Segmentina nitida, Acroloxus lacustris, and Pisidium pulcbellum. The last hardly affects the frequency and of the others the most doubtful is Planorbis planorbis which has a wide range of tolerance. The two species of the subgenus Planorbis, however, prefer fairly spacious habitats of moving water and $P$. planorbis is said to occur more commonly in ponds and ditches than the other species, carinatus (Bоycotr 1936). The shells listed as Planorbis (Planorbis) sp. are included here as they are probably P. planorhis and not $P$. carinatus, which has not been recorded from the deposit in any list.

The last group, $\mathrm{D}$, prefers moving water and more spacious habitats and includes eight species, Valvata piscinalis, Bithynia tentaculata, B. leachi var. inflata, Lymnaea stagnalis, Physa fontinalis, Pisidium amnicum, $P$. henslowanum and $P$. moitessierianum. Most of the changes in frequency of the group are caused by increases and decreases in the numbers of Bitbynia tentaculat

Planorbis laevis has not been included in any group. At present it is characteristic of low elevation mountain lakes in the northwestern parts of Britain (BoycotT 1936), but it, or a species indistinguishable from it, is very common in some Pleistocene deposits, for example Selsey, where it certainly does not indicate low elevation mountain lakes. Furthermore, there is doubt about many of the identifications, as very broken or very juvenile specimens are very difficult to distinguish from Planorbis planorbis and $P$. carinatus, so that they are recorded with a query in Table II.

Three groups of land mollusca have been separated. The first contains species which might be expected to live in marshes. These are mostly included in Boycotr's (1934) obligatory hygrophiles and commonly associated species. For this deposit they are Carychium minimum, all species of Succinea, Cocblicopa lubrica, Vertigo pygmaea, $V$. moulinsiana, $V$. angustior, Vallonia pulchella, Hygromia hisprda, Punctum pygmaeum. Euconulus fulvus, Retinella radiatula, Zonitoides nitidus and all species of Agriolimax. The only differences between this and Воусотт's groups are the substitution of Vallonia pulchella for $V$. excentricia and the inclusion of all species of Agriolimax, because of the 


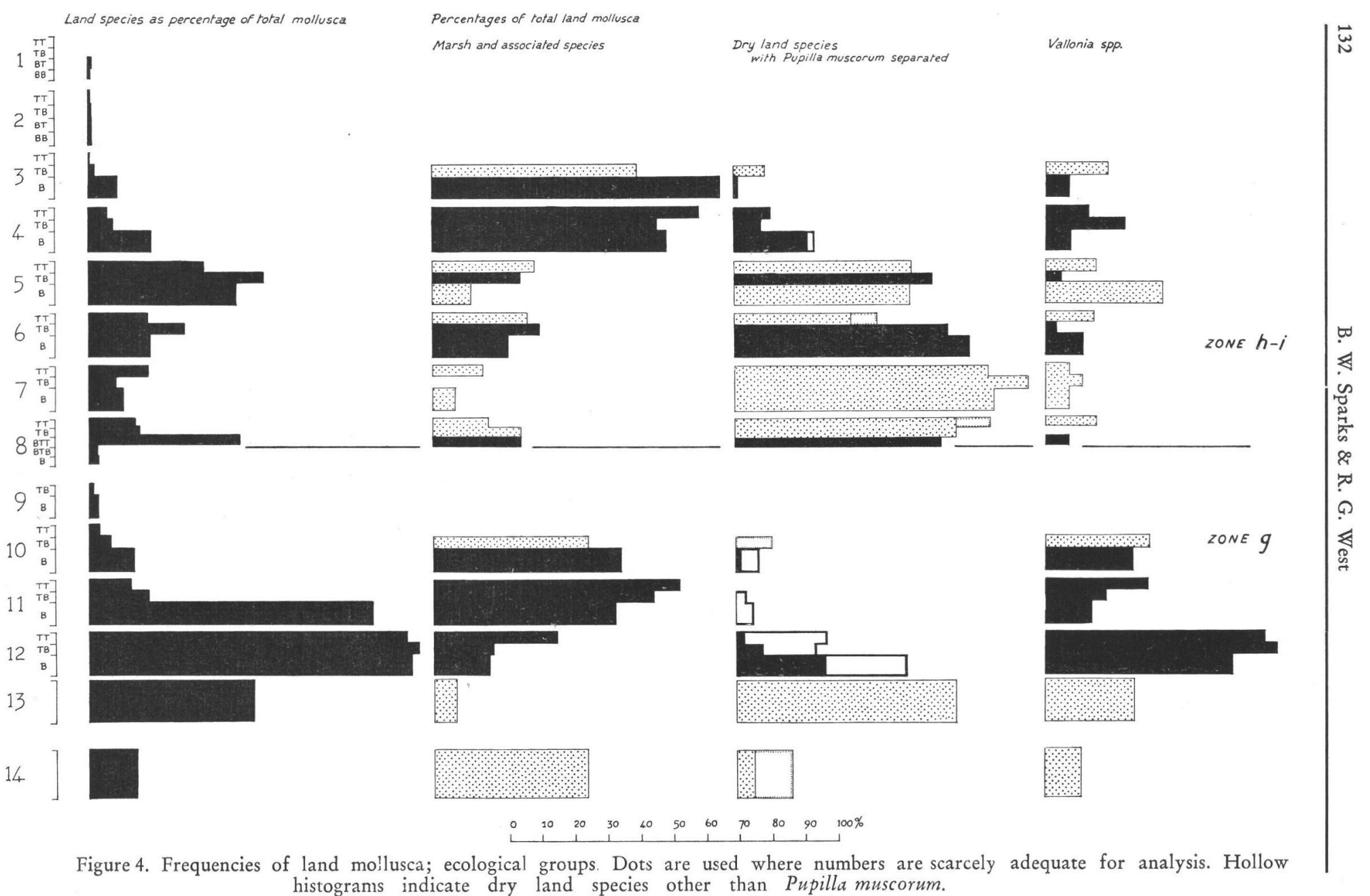


difficulty of identifying the shells of these slugs with certainty. Some of the species, notably Vertigo pygmaea, are not necessarily marsh species and may be found in much drier habitats.

The dry land group (Fig. 4) includes four species, Pupilla muscorum, Vallonia costata, $V$. excentrica and Helicella itala. Of these the first and the last are probably the most characteristic xerophiles, for Vallonia costata has been recorded in quite damp localities (ELLIS 1940), although it is not characteristic there.

The total of all the species of Vallonia is also separated, for, although pulchella is usually found in much damper localities than the other two species, none are normally found in woods. Thus, the frequency of Vallonia may be used to suggest locally open environments.

Using these various groups of mollusca, it is possible to define the various changes in local conditions thraugh the deposit. The following phases may be recognised.

Core 14 is in gravel at the base of the section and there is some doubt whether it is completely free from contamination, as the borehole was not cased to this level. However, the stream conditions suggested by the lithology are confirmed by the predominance of freshwater mollusca and by the importance of the ditch and moving water groups among them.

Core 13 is in grey silty marl, gravelly at the base and poorly fossiliferous. Land and freshwater species are present in almost equal numbers, the slum group of freshwater mollusca and the dry land group dominating. But the numbers are too small for satisfactory analysis and it is perhaps better to regard this core as a transition between stream conditions below and dry land conditions above in core 12.

Core 12 is dominated by land mollusca and represents the most truly terrestrial conditions revealed by the whole succession. The percentage of marsh species is lower than the percentage of dry land species, while Vallonia is more important at this horizon than at any other level. All three species are important (Table II), so that, although open conditions are indicated, they ranged from damp to dry. The open quality of the environment was probably local, for small open places, some damp and some drier and perhaps a foot or two above flood level, would be sufficient to account for the frequency of Vallonia. The proportion of freshwater species is too small to be separated into groups, but species of Valvata and Bitbynia, which are included in groups $\mathrm{C}$ and D, may indicate very occasional flooding of land adjacent to a stream.

Core $11 \mathrm{~B}$ is essentially a transition to marsh, a fact which may also be indicated by the transition through a mottled layer from grey to brown silty marl and by the presence of what appear to be ferruginous nodules replacing roots and stems of plants. The percentage of land mollusca decreases somewhat, while the marsh and associated species become much more important than the dry land species and Vallonia. The marsh percentage should probably be higher, as there is a large number of specimens of Carychium, which cannot be determined specifically. As C. minimum, the marsh species, is about four times as common as $C$. tridentatum, it is likely that many of these unidentifiable shells are $C$. minimum. The increase in the freshwater mollusca is mainly in the slum group, so that the transition to marsh is indicated by both land and freshwater groups. Marsh conditions are better developed at this and immediately succeeding levels than at any other horizon except perhaps cores 4 and 3B.

That part of the succession from core $11 \mathrm{~TB}$ to $8 \mathrm{~B}$ T'B inclusive may best be regarded as a slow transition. Lithologically it is all brown silty marl grading into gravel at the top of $8 \mathrm{~B}$ and in $8 \mathrm{BTB}$, although $10 \mathrm{~T} \mathrm{~T}$ is gravel and so is $9 \mathrm{TT}$, which is not included in the analysis as it seemed to be contaminated. The whole succession represents the gradual change from marsh to stream conditions. In 11TB the freshwater species are dominated by the slum group and it is highly likely that the frequency of these shown on Fig. 2 is too 
low, for most of the shells listed as Pisidium sp. are probably juveniles of $P$. obtusale which is virtually the only species of Pisidium present at this level. If this is so, the percentage of slum species should be approximately 50\% higher, as high in fact as in core 11B. Above this level there is a general decrease in the importance of slum species, until by core 8 BTB they are of no great significance. The catholic group rises to a broad peak in cores 10 and 9 above that of the slum group and then decreases upwards. The ditch group reaches a peak at a slightly higher level, from about $10 \mathrm{~T} T$ to $8 \mathrm{~B}$, and then falls, while the moving water group increases the whole way up and is highest in 8BTB. Thus, there is a successive dominance of the four groups, indicating the progression from marsh to stream conditions. The first appearance near the top of this part of the core of Pisidium amnicum and $P$. henslowanum is confirmation of the establishment of stream conditions. Unfortunately the land mollusca are too few in number for a continuous analysis to be made through this section. Their general decrease in importance is clear and to be expected from the changes indicated by the freshwater species. The beginning of the decrease in marsh species may be seen in core 9, and when there are next enough for analysis, admittedly in core 8BT'T just above the levels discussed, dry land species are much more important than marsh species.

Cores $8 \mathrm{BTT}$ to $5 \mathrm{~T}$ 'T inclusive are composed principally of light grey-brown or grey silty marls. This part of the core is characterised by a higher percentage of land mollusca than that found in the section just described, and by the dominance of moving water and catholic groups among the feswhater species. In the freshwater mollusca the change from $8 \mathrm{BTB}$ to $8 \mathrm{BTT}$ is quite sharp (Fig. 3). The moving water group remains dominant, while the ditch group falls to an extremely low proportion. Immediately above the base in 8 ' $\mathrm{TB}$ the catholic group suddenly increases. The dominance of moving water and catholic groups is upset in cores $6 \mathrm{~TB}, 6 \mathrm{~T} T$ and $5 \mathrm{~B}$ by a subsidiary peak in the slum group. Apart from this, the assumption of generally open stream conditions would account for the greatly decreased importance of those species preferring weed-filled ditches, and also for the change in the character of the land mollusca. The latter increase in importance and are dominated by dry land species almost exclusively Pupilla muscorum. In previous comments (SPARKS in WALKER 1953) it was suggested that this might have been due to the variety elongata CLessin, which is said to be characteristic of damper localities, but this is probably not the true explanation. The apertures of dead shells easily become plugged with dirt and the shell thus floats freely, so that dead shells may be washed into a stream from dry habitats and redeposited much farther down the stream. In fact the presence of $P$. muscorum, rather than a marsh fauna, seems to indicate the increased importance of stream activity.

The next recognisable phase is represented by cores $4 \mathrm{~B}$ to $3 \mathrm{~B}$ inclusive and indicates a reversion to marshy conditions. The overall proportion of land snails decreases, but the sudden increase in the marsh and associated species and the corresponding decrease in the dry land species is very striking (Fig. 4). Equally striking among the freshwater mollusca is the abrupt fall in moving water species and the spectacular increase in slum species (Fig. 3), the latter being especially marked by the increase of Planorbis leucostoma (Table II). The lithology changes to a light brown marl, which becomes much darker in 3B. This dark brown silty marl extends up to core 3T'T, where, however, the relative frequency of the groups of mollusca is very different. The marshy conditions represented are comparable with those of core $11 \mathrm{~TB}$ and were probably best developed in $3 \mathrm{~B}$, which has the highest percentage of marsh land snails as well as a significant proportion of freshwater species liking weed-filled ditches.

The general composition of the fauna changes abruptly in core $3 \mathrm{~TB}$ and remains virtually the same to the top of the section. The percentage of land mollusca is lower than at any other levels and drops to nothing in cores 1TB and 1TT. There are far too 
few to analyse them into groups. Among the freshwater mollusca the moving water group increases enormously and the other groups drop to very low levels. In fact, there is a reversion to stream conditions. It is curious that the changes do not coincide exactly with lithological changes. Grey silty marl, such as characterised the stream phase from 8BTT to $5 \mathrm{TT}$, returns in core $2 \mathrm{BT}$, but the faunal change is about a foot lower in core $3 \mathrm{~TB}$. The top two cores are involved by cryoturbation in the overlying gravel, but all the mollusca seem to come from the grey mud.

(B) Variationsindicated by the plants.

The plant remains are listed in Table III into three ecological groups, which are graphed in Fig. 5 First, aquatic species, such as Potamogeton spp., Sagittaria and Zannichellia; no distinction has been made between various categories of water plants, and all these plants are most commonly found in water bodies of varying depths. The second group includes plants characteristic of habitats of variable wetness found around the edges of water bodies, such as Alisma plantago-aquatica and Rumex maritimus, and the third includes plants of open ground, waste and grassy places, usually dry. The two right hand columns of Fig. 5 show the frequencies, as percentages of the total at each horizon of columns 1, 2 and 3, of Ranunculus-Batraclium spp., a species aggregate occupying habitats varying between groups 1 and 2, and of Urtica dioica, with habitats varying between groups 2 and 3. Trees and shrubs are not included in the grouping because of their infrequency. The percentages are only graphed where sufficient numbers of plant remains were found.

In cores 14, 13 and 12, pollen was absent and macroscopic plant remains were scarce. The molluscan fauna in these cores shows a transition from stream conditicns in core 14 to dry land conditions in core 12. In cores 13 and 12 the most frequent of the low total of seeds are those of Ranunculus-Batrachium spp., a result according with the suggestion of terrestrial conditions with very occasional flooding given by the mollusca.

The mollusca show during cores 11 to 8 a transition from dry land conditions in core 12 , through marsh in core 11 to stream conditions in core 8 . A similar change is indicated by the frequencies of the groups of plant remains. In cores 11 to 9 plants characteristic of shallow water and damp ground (group 2), including Alisma plantagoaquatica, Oenanthe aquatica, Rumex maritimus and also Ranunculus-Batrachium spp. are predominant, with their frequencies slowly falling. In core 8 the aquatic species (group 1), including Potamogeton spp., Sagittaria and Schoenoplectus, become predominant. The change in local water conditions is accompanied by the first appearance of pollen on the change from dry land to marsh conditions from core $11 \mathrm{~B}$ to $11 \mathrm{~TB}$. It is interesting to note that although the macroscopic remains show these local changes in enviroment, the pollen of the marsh and aquatic plants, as seen in Fig. 2, does not show a similar trend. Presumably the pollen rain was not so locally derived.

In cores 8 and 7 the aquatic species are dominant, and, as with the mollusca, the total number of specimens found is much reduced. The analysis of mollusca from the corresponding levels shows the dominance of moving water and catholic species.

In core 6 the group 2 species regain their predominance, but specimen totals here are far too small for much significance to be attached to the change. It does, however, correspond to an increase in the slum species of mollusca, a change which would be expected to accompany the increase of the group 2 species of plants.

The scarcity of plant remains in cores 5 and 4 prevents representation in the frequency groups. This period corresponds to an increase in the frequency of the land mollusca, though of the freshwater mollusca moving water species are dominant in core 5 and slum species in core 4. Urtica dioica is the plant most frequently represented in core 4 , as it is in core 3 . At the base of core 3 , the group 2 species, with Urtica dioica, predominate, and 


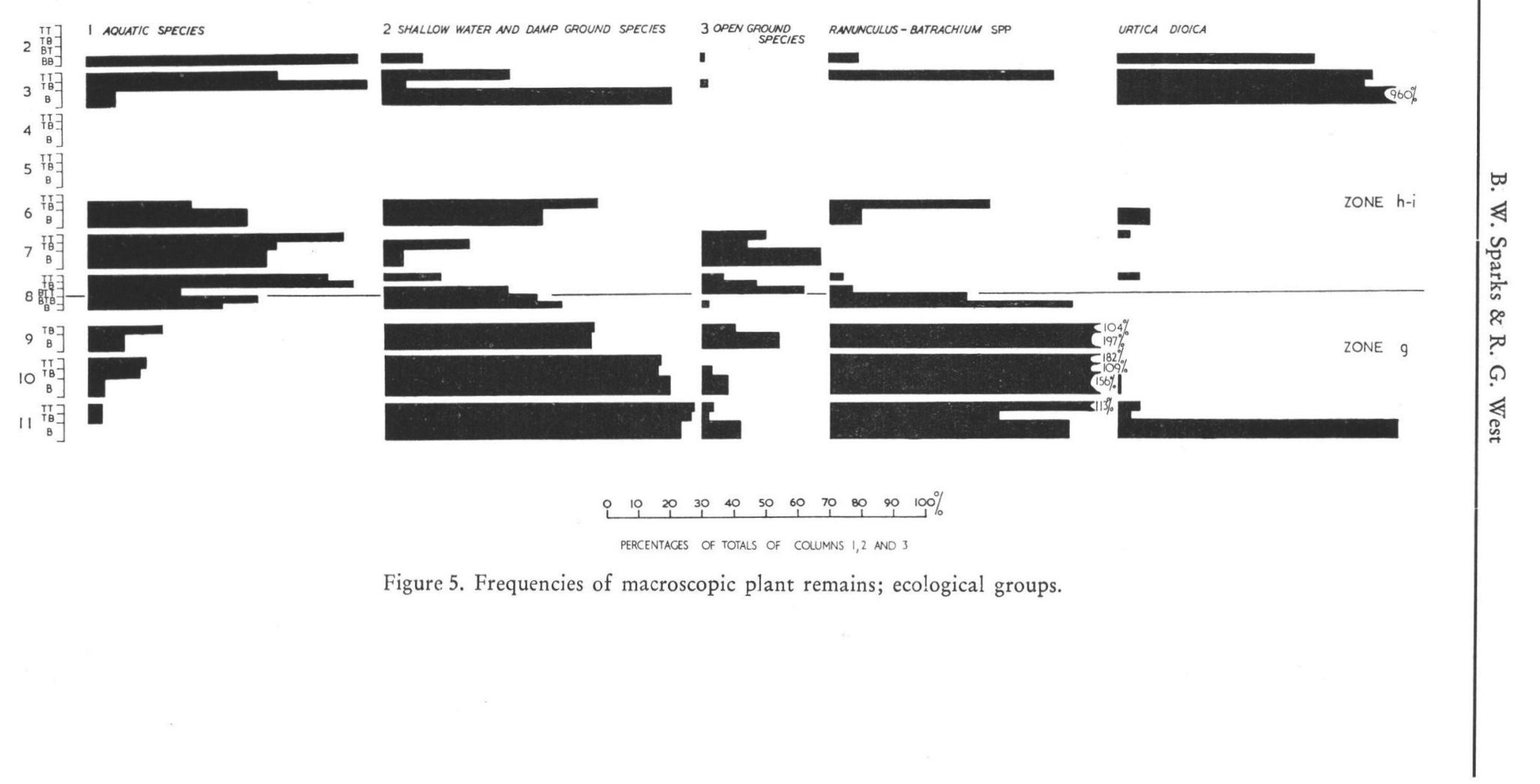


this phase is correlated with the high frequencies of the slum and ditch species of mollusca, as it was in cores 11 to 9 . The great frequencies of Urtica dioica here, together with the records of Ranunculus sceleratus, suggest the presence of shallow muddy water, with nearby riverside habitats disturbed by animals. At the top of core 3 and in core 2, the aquatic plants of group 1 (almost entirely Sagittaria, but also Potamogeton spp.) become more frequent, a change corresponding to the great increase in moving water mollusca seen at this level. The abundance of Sagittaria indicates slow movement of the water over a muddy substratum. Macroscopic plant remains were not found at any horizon above core $2 \mathrm{~TB}$, though pollen was present in places. It is not clear how far derivation affects the interpretation of the plant remains from these upper cores.

The land species, group 3, show a gradual but irregular increase from core 11 to core 7. The peak in core 9 is caused by a temporary abundance of the seeds of Chenopodium section Pseudoblitum, and corresponds to the peak in the pollen of Chenopodiaceae at the same level. Species of this section of Chenopodium are characteristic of waste ground, and they may be frequent near the sea. The finds of Rorippa islandica at the same level as Chenopodium subsection Psendoblitum are of interest, as Chenopodium rubrum, the most common British species of the section Pseudoblitum, is often found with Rorippa islandica (and Bidens cernuus, a species recorded from the same level) in moist places by streams with standing water in winter, a habitat agreeing well with the conditions suggested by the mollusca. The relatively high frequencies of group 3 species in cores 8 and 7 are caused by the presence of few specimens of a number of species, including Anthriscus sylvestris, Chenopodium sp., Cirsium cf. vulgare, Euphorbia cyparissias agg., Linum anglicum, Pastinaca sativa, Petroselinum segetum, Picris hieracioides, Plantago major, Polygonum aviculare agg. and Sonchus arvensis. The increase in this group of species presumably corresponds to the increase of the non-tree pollen, notably of Gramineae, Compositae and also Centaurea scabiosa, as the transition from zone $g$ to zone $b-i$ takes place.

The abundance of land species in cores 7 and 8 corresponds to the high frequency of the dry land mollusc Pupilla muscortum, but the latter continue in core 6, where no group 3 species are found.

It will be seen that the group 3 species reach a maximum at the same time as the group 1 species; it is possible that an explanation similar to that given for the abundance of Pupilla muscorum under stream conditions may apply, i.e., that plant remains from dry habitats are more likely to be washed down and deposited with the remains of aquatic plants under conditions of running water than if the stream is sluggish, when the more local elements of the flora will predominate.

In cores 3 and 2 the group 3 species are scarce, the locally growing aquatics and damp ground elements of the flora being dominant, as with the mollusca.

(C) Conclusions.

The succession of environments indicated by the fauna and flora is from stream conditions in core 14 , to dry land in core 12 , to marsh in core 11 , a slow change back to stream conditions by core 8 , a continuation of these conditions to core 5 , a reversion to marsh in cores 4 and $3 \mathrm{~B}$, and an equally sudden change back to stream conditions above. These changes might be explained partly by a meandering stream swinging across its own floodplain, though the relative rates of deposition and meander shift are too imperfectly known for it to be decided whether there are sufficient sedimentary or faunal "cycles" for this explanation to apply. The thickness of the sediment analysed, some 20 feet, must indicate aggradation, though whether due to a rising base-level or to an increase in the load-discharge ratio in the stream is uncertain. The rising base-level seems unlikely in view of the fact that during the time of the conifer pollen zones in the latter half of the 
Eemian Interglacial on the continent the Eem Sea was undergoing regression (G. v. D. BreLIE 1954). There is no indication from the mollusca of salt or brackish water conditions at any level. Neither do the plants give any certain indication of such conditions, though perhaps some are suggestive of maritime conditions not too far away, e.g. Apium graveolens in core 10, Chenopodium section Pseudoblitum in cores 10 and 9, and the pollen of Armeria (more Armeria pollen was recorded by WALKER 1953) and of Plantago maritima, the former in core 5 , the latter in cores $9,8,7,6$ and 5 .

\section{Variations in climate through the deposit}

\section{(A) Variations indicated by the mollusca.}

In the analysis of the Bobbitshole mollusca (Sparks 1957), it was found possible to plot the frequencies of individual species, as well as groups of species, because the local conditions changed slowly and to a far smaller degree than in this deposit. The plotting of individual frequencies through the Histon Road deposits is pointless, because of the abrupt changes in local conditions. This may be appreciated, for example, by considering the abrupt drop in Valvata cristata and Planorbis leucostoma between cores 3B and 3TB and the even more abrupt rise of Bitbynia tentaculata at the same level. Yet these three species are all highly tolerant climatically.

Accordingly all species, the distributions of which can be obtained with some certainly from Geyer (1927), EhrmanN (1933) and Hubendick (1947), have been classed into four groups depending largely on their range northwards into interior Scandinavia. These groups are indicated in the first column on Table II. Species classed group A reach well to the north, almost to or within the Arctic Circle in Sweden. Group B reaches approximately $63^{\circ} \mathrm{N}$. in Sweden, while group $C$ reaches $60-61^{\circ} \mathrm{N}$., i.e. approximately the northern limit of the oak in Sweden. Species in group D reach only the very south of Scandinavia or are confined to the European mainland. There is a certain amount of doubt concerning some of the distributions: with the slug genus Agriolimax and with some species of Pisidium because of identification difficulties; with Limax sp. because, altough most species would be classed as group B, the actual species is not known; with Planorbis laevis, because, in spite of Boycotr's indication of a north-western distribution in low-level mountain lakes in Britain, it does not seem to reach very far north in Scandinavia.

It is evident from Fig. 6, as it was from the Bobbitshole material, that the most tolerant species dominate even in the middle of an interglacial, but the proportion of the most tolerant group, A, does increase steadily up through the deposits as the climate deteriorates. The low frequencies in cores 12 and 11, except in 11B, are due to the large number of specimens of Vallonia, which cannot be determined specifically. In 11B the low frequency of group A and the high frequency of group B are due to the large numbers of Carychinim, which was apparently favoured by local conditions. Group B, apart from the drop from the peak in 11B, does not begin to decrease greatly until core $3 \mathrm{~TB}$ : in fact it shows a secondary maximum in cores 6 to $3 \mathrm{~B}$. Whether this is comparable with the intermediate maximum on the less tolerant group at Bobbitshole (SPARKs 1957, Figs. 1 and 2) is uncertain, as the same species are not involved. It may be merely an effect of local environmental conditions. Group $C$ is at a maximum near the bottom and decreases steadily from core 6 upwards, while group $\mathrm{D}$ almost disappears above the middle of core 8 .

The frequencies of these groups, which are based solely on present distribution of the species, clearly shows that the general climatic trend may be derived from a frequency analysis of mollusca species or groups, in spite of the complicating effects of changes in local conditions. The virtual disappearance of the least tolerant group, $D$, at the end of pollen zone $g$ is interesting, though it may be safer to regard it as a coincidence until more 


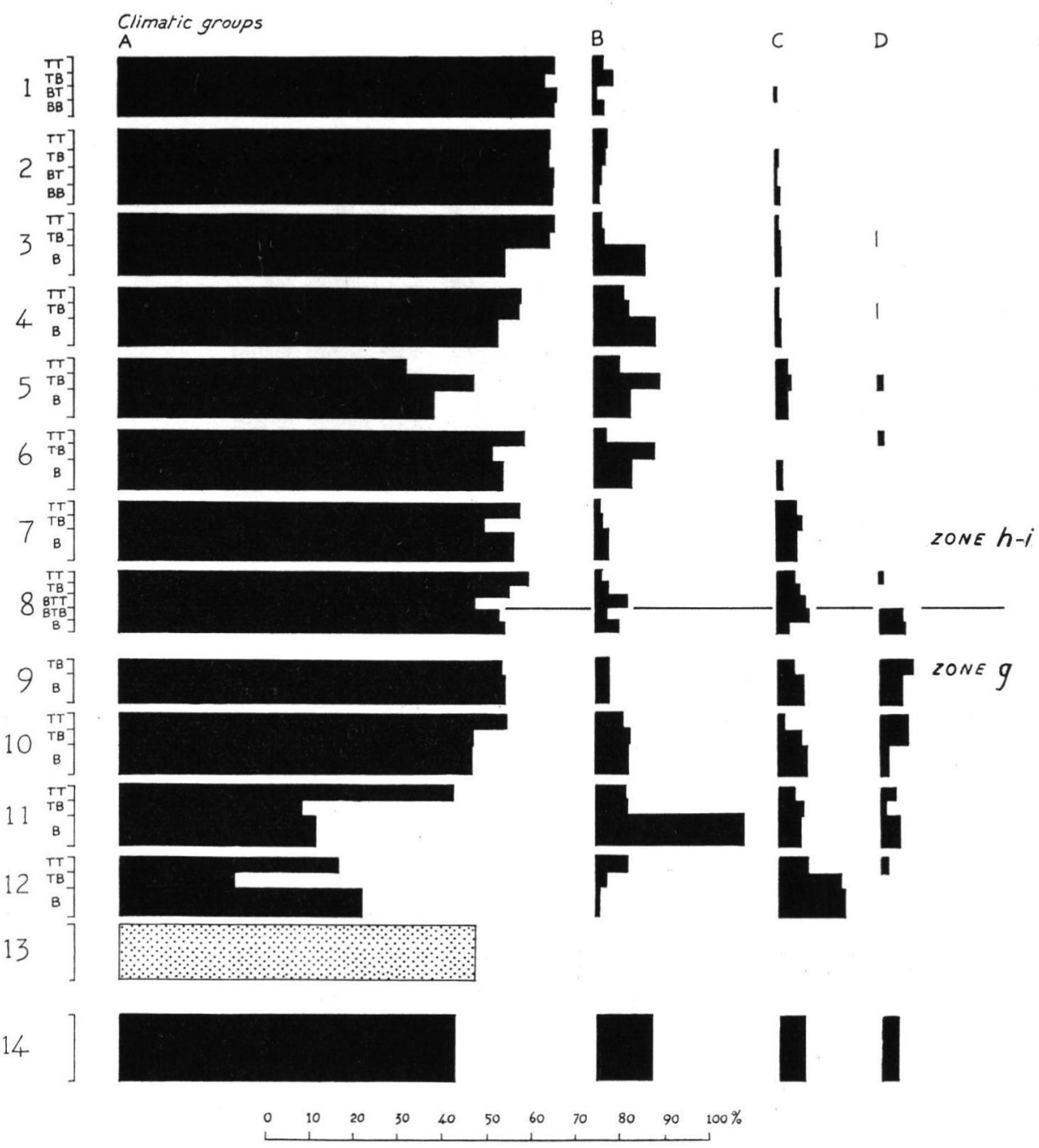

Figure 6. Frequencies of mollusca; climatic groups. Dots are used where numbers are scarcely adequate for analysis.

data from other deposits are available. It seems that the less tolerant mollusca linger on after the middle of the interglacial into zones with more northern vegetation, e.g., the pine-birch period of zone $b-i$, than that characteristic of the vegetation zone in which they were introduced, for many of the species in groups $\mathrm{B}$ and $\mathrm{C}$ were not really introduced until zone $e$, the birch-pine-oak zone at Bobbitshole. This relationship might have been expected, for immigration in the first half of an interglacial must depend on rate of migration as well as climatic improvement, while extinction in the second half is probably principally a function of climate. The interpretation of a fauna at a given level, then, will depend partly on knowing which part of the interglacial it belongs to. At the top of the section the complete dominance by very tolerant British freshwater species is comparable with conditions in the early parts of the interglacial, for example at the bottom of the Bobbitshole section. 


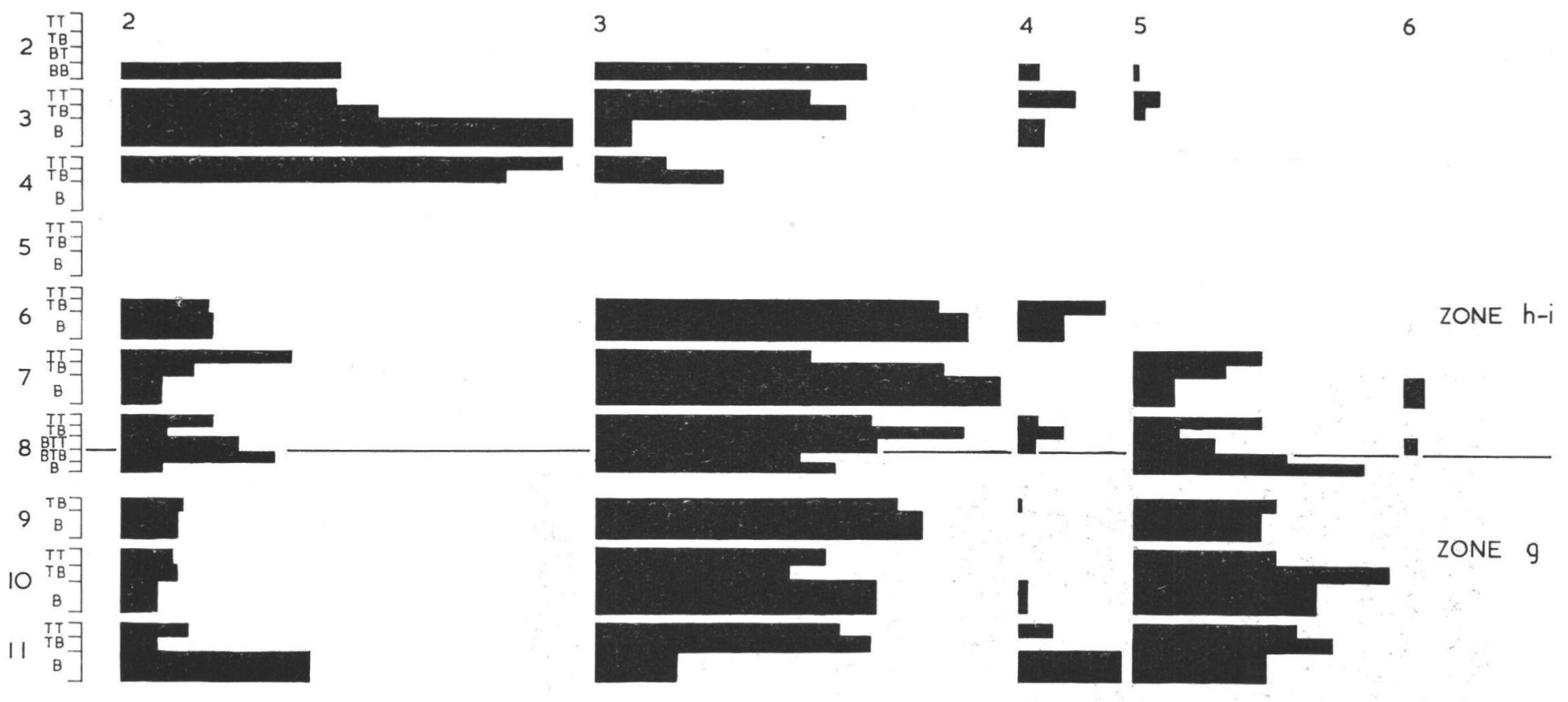

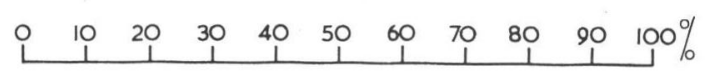

Figure 7. Frequencies of macroscopic plant remains; distribution groups. 
(B) Variations indicated by the plants.

The plants recorded by their macroscopic remains were assigned where possible to five plant-geographical groups, as shown in Table III. These categories of distribution are those which were used in the analysis of the plant remains from Bobbitshole (WEST 1957), and are made for use with Hultén's (1950) Atlas of the distribution of vascular plants in N. W. Europe. They are:

2. Plants distributed throughout Scandinavia.

3. Plants with northern limits in Scandinavia near the Arctic Circle.

4. Plants with northern limits in Scandinavia about midway between those in categories 3 and 5.

5. Plants with northern limits in the south of Scandinavia.

6. Plants with northern limits in north-west Europe south of Scandinavia.

Figure 7 shows the percentage frequency of specimens of species of each group horizon by horizon. Ideally an analysis of this kind should be expected to reveal long term climatic fluctuations (here the analysis is "north-south", but an "east-west" or oceaniccontinental analysis or an analysis of the effects of climatic change on the different ecological groups might be possible in other deposits).

In the Histon Road deposits, however, the interpretation of the frequency graph is complicated by the possibility of secondary deposition in the upper cores, and by the small numbers or absence of macroscopic remains in the middle cores.

A general trend of change in distribution type is apparent. In the lower cores, plants of groups 3 and 5 are most abundant, and in the upper cores, plants of groups 2 and 3 . These changes are similar to those shown by the mollusca and record the deterioration of climate in the latter half of the interglacial. In the Carpinus zone $g$, there is a large proportion of specimens of species now only reaching northward in Scandinavia as far as the southern half of Sweden, a group including also certain plants identified by their pollen, e.g. Quercus, Carpinus, Corylus, Hedera, Ilex, Centaurea scabiosa and Poterium sanguisorba. The predominance of these thermophilous plants, together with the high frequencies of the pollen of Carpinus betulus, a tree with an essentially central European distribution, indicates a relatively warm climate, probably rather continental.

In zone $b-i$ the more northern character of the vegetation is shown by the fall in frequency of the pollen of Quercus, Carpinus and Corylus. However, species of distribution categories 4,5 and 6 are present in zone $b-i$, in particular such southern and continental species as Linum anglicum and Petroselinum segetum amongst the land flora, and such a comparatively southern species as Potamogeton acutifolius amongst the aquatics. As with the mollusca, it appears that certain rather southern species linger on into the pine-birch zone.

At the top of the succession species of groups 5 and 6 have virtually disappeared, and the dominant species have a wide range northwards into Scandinavia. It is not certain whether these upper frequencies have been affected by the secondary deposition already suggested to explain the anomalous behaviour of the pollen curves.

\section{$\mathrm{X}$. The question of secondary deposition}

The curious nature of the pollen diagram from the top of core 3 has been discussed and attributed to secondary deposition. The question immediately arises whether the abrupt changes in mollusca and significant changes in macroscopic plant remains may be due to the same cause.

The main molluscan change is the enormous increase of Bithynia tentaculata, a species possessing a resistant operculum which is liable to be found derived from earlier beds. The figures quoted in Table II for this species are counts of opercula, which are always more 
frequent than shells because they are less readily smashed, but the numbers of opercula exceed the numbers of shells at each horizon usually by a third or less, quite a normal figure and not one for the explanation of which a hypothesis of secondary deposition is required. From this it seems that the changes in freshwater mollusca may be a reflection of the more powerful stream which was responsible for introducing the derived pollen.

However, when one looks at the earlier records of mollusca, some features appear which may well be due to secondary deposition. Helicella crayfordensis has been recorded from the overlying gravel in 1953 (SPARKS in W ALKER). Both of these must be in zone from the uppermost horizon, depth 3 metres, in 1950 and from material reputed to come $h-i$ and so must the record of Corbicula fluminalis (Hollingworth, Allison \& Godwin 1950) at a depth of 3.5-4 metres. The latter is a tough shell which might well stand redeposition and the former is certainly more characteristic of the middle of interglacials than the ends.

Whether the shells are redeposited or manage to survive in a climate of increasing severity for a considerable time is immaterial from a geological viewpoint: the important thing is that the presence of southern species in the second half of an interglacial does not necessarily mean the same as it would in the first half, where southern species seem to come in quite late (SPARKs 1957). It emphasises the need to examine if possible a succession of horizons to see whether a climatic tendency can be established before interpreting a fauna containing isolated southern species. From a biogeographical viewpoint it is unfortunate that it seems possible to do no more than guess what has been redeposited and what has not.

\section{Notes on certain species of mollusca}

Bithynia leachi var. inflata. The number recorded probably represents a minimum as most of the shells are broken and the operculum does not always appear to be a safe guide.

Planorbis planorbis. Probably the very broken and juvenile material recorded as Planorbis (Planorbis) sp. belongs to this species, as no trace of $P$. carinatus has ever been found in these beds.

Planorbis laevis certainly occurs, though very broken and juvenile material is difficult to separate from Planorbis (Planorbis) spp. - hence the doubt expressed at some horizons in Table II.

Planorbis leucostoma includes the two forms which might be recorded as spirorbis and leucostoma, the latter being more depressed and having more gradually increasing whorls.

Cocblicopa lubrica. Altough most of the specimes of Cocblicopa are apical fragments, they seemed too inflated for any to be attributed to C. lubricella.

Azeca goodalli. As far as can be seen all specimens should be referred to A.menkeana $\mathrm{C}$. PFeiffer. The questions of the systematic position of this 'species' and its distribution, recent and fossil, were being considered by Mr. Hugh WATson before his recent untimely death.

Vertigo moulinsiana. Only the upper half of a shell was seen and this was lost. Hence, it is recorded with doubt.

Arianta and Cepaea. Although the presence of both genera was established from the ornamentation of fragments of the outer whorls of the shells, the worn apices of the two genera cannot be separated.

Hygromia liberta is the form with a more raised spire and very narrow umbilicus often regarded as a distinct species and recorded by Kennard in the 1950 list.

Agriolimax species are recorded with doubt because of difficulties of recognition discussed elsewhere (SPARKS 1957). The forms of the shells attributed to the species are the same as those illustrated in that paper (Plate I, Fig. $g$ and Plate II, Figs. $b-j$ ).

Sphaerium lacustre is based mainly on counts of presumed prodissoconchs. These seem to separate cleanly from the rest of the shell and to be very different in detailed character from immature Pisidia, which they resemble in size. A few have parts of the almost straight dorsal margin attached.

\section{Report on mosses from the interglacial deposits at Histon Road, Cambridge}

by M. C. F. Proctor

(Department of Botany, University of Exeter)

The Bryophyte remains examined consist entirely of hypnoid mosses. They include a number of well-preserved pieces of leafy shoots, but a good deal of the material is rather fragmentary and often corroded, so that some of the identifications are necessarily tentative. Nomenclature in 
the list below follows the check-list by Richards \& WaI.LACE in Volume 1 of the Transactions of the British Bryological Society.

Cratoneuron filicinum. Well preserved leafy shoots in 7 TB and $7 \mathrm{~B}$.

Amblystegium kochii. Well preserved leafy shoot in 8 TT.

Drepanocladus cf. aduncus. Fragments probably referable to this species in $9 \mathrm{~B}$ and $10 \mathrm{TT}$.

Drepanocladus cf. fluitans. 9 TB and the samples from 10 TT downwards contain abundant remains of a Drepanocladus which is almost certainly this species. A little D. exannulatus may be included.

Drepanocladus sp. 7 TT.

Acrocladium cordifolium. A short piece of leafy shoot in 9 B.

Camptothecium nitens. Common in the higher samples, from $7 \mathrm{~B}$ to $8 \mathrm{BTB}$, usually as short pieces of leafy shoot.

cf. Brachythecium rutabulum. A large but somewhat corroded leafy shoot in 8 TT.

cf. Eurbynchium praelongum. $8 \mathrm{BTB}$ and $11 \mathrm{~TB}$.

cf. Eurbynchium sp. 8 BTT.

The lower samples, with abundant Drepanocladus fluitans, suggest a well-developed mildly acid fen. Those from 8 BTB upwards suggest more calcareous and drier conditions. The samples as a whole, and in particular the higher samples with Camptothecium nitens, suggest a relatively cool temperate climate. C. nitens is much commoner in Scandinavia than in Britain at the present day, though it must be remembered that it is widepread in central Europe, and has widely scattered localities in Britain at the present day; it has been at least locally abundant in Britain during the Post-glacial Period.

\section{References}

Andersen, S. T., 1957: New investigations of interglacial fresh-water deposits in Jutland. A preliminary report. - Eiszeitalter und Gegenwart 8, S. 181-186.

Boycotт, A. E., 1934: The habitats of land mollusca in Britain. - J. Ecol. 22, S. 1-38. - - 1936: The habitats of freshwater mollusca in Britain. - J. Anim. Ecol. 5, S. 116-86.

Christr, M., 1924: The hornbeam in Britain. - J. Ecol., 12, S. 39-94.

Ehrmann, P., 1933: Die Tierwelt Mitteleuropas II(i). Mollusken (Weichtiere). - Leipzig.

ELLIS, A. E., 1940: The mollusca of a Norfolk broad. - J. Conch. 21, S. 224-243. - - 1951: Census of the distribution of British non-marine mollusca. - Ibid., 23, S. 171-244.

FAEGRI, K., \& Iversen, J., 1950: Textbook of modern pollen analysis. - (Munksgaard) Copenhagen.

GEYER, D., 1927: Unsere Land- und Süßwasser-Mollusken. 3rd. ed. Stuttgart.

Hollingworth, S. E., Allison, J. \& Godwin, H., 1950: Interglacial deposits from the Histon Road, Cambridge. - Quart. Journ. Geol. Soc. London, 105, S. 495-510.

Hubennick, B., 1947: Die Verbreitungsverhältnisse der limnischen Gastropoden in Südschweden. Zool. Bidr. Uppsala, 24, S. 421-559.

Hultén, E., 1950: Atlas of the distribution of vascular plants in N.W. Europe. - Generalstabens Litografiska Anstalts Förlag, Stockholm.

Jessen, K. \& Mrlthers, V., 1928: Stratigraphical and palaeontological studies of interglacial fresh-water deposits in Jutland and northwest Germany. - Danm. Geol. Unders., II Raekke, Nr. 48.

Sparks, B. W., 1953: Fossil and recent English species of Vallonia. - Proc. Malac. Soc. London, 30, S. 110-121. - - 1957: The non-marine mollusca of the interglacial deposits at Bobbitshole, Ipswich. - Phil. Trans. Roy. Soc. London, B, 241, S. 33-44.

Thomson, P. W., 1951: Das Interglazial von Wallensen im Hils. - Eiszeitalter und Gegenwart, 1, S. $96-102$.

voN DER BrELIE, G., 1954: Transgression und Moorbildung im letzten Interglazial. - Mitt. geol. Staats-Inst. Hamburg, 23, S. 111-118.

WALKER, D., 1953: The interglacial deposits at Histon Road, Cambridge. - Quart. Journ. Geol. Soc. London, 108, S. 273-282.

West, R. G., 1956: The Quaternary deposits at Hoxne, Suffolk. - Phil. Trans. Roy. Soc. London, B, 239, S. 265-356. - - 1957: The interglacial deposits at Bobbitshhole, Ipswich. - Ibid., 241, S. $1-32$.

Manuskr. eingeg. 4. 2. 1959.

Anschrift der Verf.: Mr. B. W. Sparks, Department of Geography, University of Cambridge, Cambridge/England. - Dr. R. G. West, Department of Botany, University of Cambridge, Cambridge/England. 